\title{
POLSKO-SŁOWACKA WSPÓtPRACA TRANSGRANICZNA W REGIONIE TATR PO 1918 ROKU
}

T atry i Podtatrze to jeden z najbogatszych kulturowo regionów Polski i Słowacji. To obszar górski, który jednak nigdy nie dzielił, a zawsze łączył zamieszkujące go wielokulturowe społeczności. Bliskość kulturowa, językowa, a także wspólne dziedzictwo historyczne regionu wpływały w przeszłości na rozwój kontaktów między mieszkańcami pogranicza. Stało się to przyczynkiem do powstawania na tym obszarze już w latach 20. XX wieku pierwszych transgranicznych jednostek terytorialnych. Z reguły były to wspólne obszary chronione i konwencje turystyczne. Na początku lat 90. rozpoczął się proces pogłębiania instytucjonalizacji współpracy transgranicznej $\mathrm{w}$ regionie. Jego zwieńczeniem stała się podjęta w 2007 roku decyzja Euroregionu Tatry o przekształceniu się w Europejskie Ugrupowanie Współpracy Terytorialnej.

Celem niniejszego artykułu jest analiza najważniejszych form współpracy transgranicznej w regionie Tatr i Podtatrza po 1918 roku. Analiza zostanie przeprowadzona chronologicznie, z podziałem na etapy. Przedmiotem badań pierwszej części tekstu będzie polsko-czechosłowacka współpraca transgraniczna w okresie międzywojennym. Kolejnym analizowanym okresem, w którym rozwijały się nieliczne inicjatywy transgraniczne, są czasy komunistyczne. W ostatniej części pracy scharakteryzowany zostanie Euroregion Tatry, a także nowa instytucja prawna UE - Europejskie Ugrupowanie Współpracy Terytorialnej, w którą wspomniany euroregion planuje się w najbliższych miesiącach przekształcić.
Mgr Łukasz LEWKOWICZ jest doktorantem na Wydziale Politologii Uniwersytetu Marii Curie-Skłodowskiej w Lublinie. lewkowicz83@gmail.com 
Nowa sytuacja polityczna, jaka powstała po zakończeniu I wojny światowej w Europie Środkowej, otworzyła kolejny etap w polsko-słowackiej współpracy transgranicznej. W wyniku klęski militarnej Austro-Węgier w październiku 1918 roku na byłym pograniczu polsko-węgierskim, głównie w regionie Spiszu i Orawy, wytworzyła się swego rodzaju próżnia polityczna'. Wkrótce obszar ten stał się miejscem rywalizacji między nowo powstałymi Polską i Czechosłowacją. Jednym z głównych zadań odbudowującego się w tamtym okresie państwa polskiego, obok likwidacji obcej władzy oraz organizowania własnych instytucji państwowych, stała się kwestia ustalenia granic. Przy określaniu ich przebiegu z jednej strony pod uwage brane były tradycje granic przedrozbiorowych, z drugiej zaś dążono do włączenia w granice Polski tylko tych terenów, w których dominowała ludność polska. W przypadku karpackiego odcinka granicy chodziło przede wszystkim o północny Spisz, Orawę i Czadeckie².

Republika Czechosłowacka, mimo że nie stanowiła kontynuacji polityczno-prawnej Królestwa Węgierskiego, domagała się na odcinku północnym takiej samej granicy, jaka istniała między Węgrami a Galicją do 1918 roku. Dążyła więc do przejęcia całego Spiszu, Orawy i Czadeckiego, łącznie z terenami zamieszkanymi przez ludność polską. Także Polska prowadziła działania mające na celu przyłączenie wspomnianych terytoriów, uzasadniając to faktem, że miały one etnicznie, kulturowo i historycznie polski charakter. Poza tym o polską pomoc zwróciła się część przedstawicieli tamtejszej ludności. Wyraźna rozbieżność stanowisk Polski i Czechosłowacji w kwestii wspólnej granicy była przyczyną ciągnącego się przez cały okres międzywojenny poważnego sporu między obu państwami ${ }^{3}$.

Żądania terytorialne Polski względem pogranicza stały na gruncie prawa do samostanowienia narodów, jako podstawowej zasady organizacji życia politycznego i państwowego w Europie Środkowej po I wojnie światowej. Polubowne załatwianie sporu z Czechosłowacją nie przyniosło jednak spodziewanych rezultatów. W tej sytuacji władze polskie zwrócity się do Rady Najwyższej Mocarstw Sprzymierzonych z propozycją rozstrzygnięcia sporu granicznego za pomocą plebiscytu. Organ ten 11 września 1919 roku przychylit się do polskiego wniosku i zezwolit na przeprowadzenie plebiscytu na Spiszu, Orawie i Śląsku Cieszyńskim. Obszar plebiscytowy, wbrew stanowisku polskiemu, został jednak znacznie okrojony i nie objął ziemi czadeckiej i części Spiszu. Mimo to władze czechosłowackie sprzeciwiły się planowanemu plebiscytowi prognozując, że na wskazanych terenach zwycięstwo może odnieść strona polska4.

Sytuacja międzynarodowa sprzyjała zdecydowanie stronie czechosłowackiej. W lecie 1920 roku konflikt polsko-bolszewicki wszedł w decydującą fazę. W chwili, gdy wojska bolszewickie zbliżały się do Warszawy, Czechosłowacja, wspólnie z Niemcami, odmówiła przepuszczenia amunicji i sprzętu wojskowego dla armii polskiej, co znacznie pogorszyło położenie militarne państwa polskiego. Sytuacja na froncie wschodnim ostatecznie przesądziła o negatywnym dla Polski rozwiązaniu sporu. W trudnych warunkach politycznych i militarnych, za obietnice poparcia państw europejskich, premier Władysław Grabski, zde-

\section{$\cdots \cdots \cdot$}

E. Orlof, Orawa i Spisz w latach 1918-1920, [w:] T. Trajdos (red.), Spisz i Orawa. W 75. rocznice powrotu do Polski pótnocnych cześci obu ziem, Kraków 1995, s. 12.

2 J. Roszkowski, Dzieje najnowsze (1918-1999), [w:] W. Skupień (red.), Tatry i Podtatrze, Zakopane-Poprad 2000, s. 224.

3 Idem, Ksztaltowanie się południowej granicy Polski na odcinku stowackim 1918-1938, „Prace Komisji Historii Wojskowości" 2004, nr 3, s. 52-53.

4 O obawach władz czechostowackich dotyczących prawdopodobnej wygranej polskiej w Trstenie i Namestovie donosit wywiad polski w trakcie konferencji w Spa. Ibidem, s. 60. 
cydowat się na konferencji w Spa (10 lipca 1920 roku) na rezygnację z przeprowadzenia plebiscytu, jednocześnie oddając rozstrzygnięcie sporu w ręce państw Ententy. Na podstawie porozumienia w Spa, Konferencja Ambasadorów dokonała 28 lipca 1920 roku arbitralnego podziału Spiszu i Orawy, w wyniku czego Polska uzyskała jedynie 27 miejscowości (z 71 leżących na obszarze plebiscytowym) położonych w północnych częściach obu obszarów ${ }^{5}$. Z przyłączonych terenów utworzone zostało starostwo spisko-orawskie stanowiące unikatową w skali kraju jednostkę samorządową. Blisko 45 tys. osób polskiego pochodzenia pozostało po czechosłowackiej stronie granicy6.

Spór terytorialny o przebieg granicy polsko-czechosłowackiej nie został jednak ostatecznie rozstrzygnięty. Postanowienie Konferencji Ambasadorów dopuszczało przy delimitacji nowej granicy możliwość przeprowadzenia pewnych zmian. Władze polskie liczyły na możliwość odzyskania Jaworzyny Spiskiej wraz z częścią Tatr, na zasadzie wymiany terytoriów z Czechosłowacją7. Ich zdaniem strona czechosłowacka, uzyskując w 1920 roku na wszystkich spornych odcinkach granicy z Polską korzystne dla siebie rozwiązania, powinna ustąpić w sprawie Jaworzyny. Niestety oba państwa nie doszły do kompromisu nawet przy delimitacji granicy. Władze czechosłowackie przeprowadziły w Europie Zachodniej skuteczną akcję dyplomatyczną, wskutek czego nie zrealizowany został wniosek Międzynarodowej Komisji Delimitacyjnej z 25 września 1922 roku, która przyznawał Polsce ok. 3/5 spornego terytorium. Strona czechosłowacka, licząc na pozytywny dla siebie wynik, dążyła do przeciągnięcia ostatecznego rozstrzygnięcia sprawy. Była ona wielokrotnie rozpatrywana przez Konferencję Ambasadorów, dwukrotnie przez Radę Ligi Narodów, a także przez Stały Trybunał Sprawiedliwości Międzynarodowej w Hadze. Ostatecznie 12 marca 1924 roku Liga Narodów wydała niekorzystną dla Polski decyzję, pozostawiającą cały sporny obszar po stronie czechostowackiej ${ }^{8}$.

Zakończenie sporu o Jaworzynę pozwoliło na podjęcie na nowo idei tworzenia wspólnych transgranicznych obszarów ochronnych. Obie strony sporu uznały, że niezbędne jest podjęcie współpracy w zakresie ochrony przyrody, a także turystyki transgranicznej ${ }^{9}$. Projekt objęcia ochroną całych Tatr pojawił się po raz pierwszy w tzw. Protokołach krakowskich opracowanych 6 maja 1924 roku przez polską i czechosłowacką delegację rzą-

\section{......}

5 K. Gawron, Stosunki polsko-czechostowackie w latach 1918-1939 jako przyczynek do badań nad konfederacją polsko-czechostowacką 1939-1943, [w:] P. Tomaszewski (red.), Historia i polityka. Studia z historii myśli politycznej i idei, t. I, Toruń 2004, s. 57-58.

6 Istniejące w latach 1920-1925 starostwo było jedynym w Polsce obszarem, w którym obowiązywało ustawodawstwo węgierskie. Ponadto podległe mu terytorium składało się z dwóch oddalonych od siebie o 30 km części, a jego władze rezydowały na terenie innego powiatu, w Nowym Targu. Powyższy podział wymusit utworzenie dwóch oddzielnych ekspozytur starostwa: jednego dla Spiszu, drugiego dla Orawy, co stanowiło nowość w polskim ustroju administracyjnym. Ostatnią specyficzną cechą starostwa stanowit jego komisaryczny charakter. Była to jedyna jednostka administracyjna, która z założenia miała funkcjonować tymczasowo, do chwili ostatecznego ustabilizowania się sytuacji na południowym pograniczu. Zob. J. Roszkowski, Organizacja i funkcjonowanie starostwa spisko-orawskiego 1920-1925, [w:] J. Adamczyk (red.), Dwa państwa-trzy narody. Ustroje polityczne Polski i Czechostowacji (1918-1939). Warszawa 2004, s. 138-146.

7 Wcześniej udało się pomyślnie wymienić Suchą Górę i Głodówkę na leżącą po stronie czechostowackiej część Lipnicy Wielkiej.

8 M. Orłowicz, Jaworzyna Spiska, „Ziemia” 1922, nr 1, s. 16-24; A. Chybiński, Jaworzyna dla Polski, „Wierchy" 1923, nr 1, s. 3-12; T. Modelski, Na marginesie sporu o Jaworzyne, "Wierchy” 1924, nr 2, s. 183-191; W. Goetel, Spór o Jaworzynę Spiską a Park Narodowy Tatrzański, „Wierchy” 1925, nr 3, s. 14-15; V otázke Javoriny, „Krásy Slovenska” 1923, nr 4, s. 142-144; Javorina - Naša, "Krásy Slovenska” 1923, nr 6, s. 209211; P. Jelinek, Zahraničně-politické vztahy Československa a Polska 1918-1924, Opava 2009, s. 184-198; J. Roszkowski, Kształtowanie..., s. 66-67.

9 Po zapadnięciu decyzji w sprawie Jaworzyny strona polska stanęła przed wyborem dwóch sposobów uregulowania stosunków bilateralnych ze strona czechosłowacka. Pierwszy z nich zakładał kwestionowanie słuszności decyzji Ligi Narodów i permanentny konflikt z Czechosłowacją. Drugi natomiast miał na celu normalizację wzajemnej współpracy poprzez stworzenie transgranicznej konwencji turystycznej, a także podjęcie działań na rzecz utworzenia parków natury, obejmujących tereny obu państwa. Dla dobra wzajemnych relacji, a także korzyści mieszkańców pogranicza, wybrana została druga koncepcja. Szerzej: W. Goetel, Spór o Jaworzynę..., s. 10-42 
dową przy Międzysojuszniczej Komisji Delimitacyjnej. W dokumencie tym zobowiązano komisarzy granicznych obu państw do przedstawienia swoim rządom projektu konwencji dotyczącej utworzenia na wspólnych pograniczu sieci parków natury. Materiały do rokowań i projekt konwencji obie delegacje rządowe przy Komisji Granicznej, a także zaproszeni eksperci, zaprezentowali podczas zorganizowanego w dniach 6-8 września 1924 roku spotkania w Zakopanem. Na kolejnej konferencji naukowej w Krakowie (8-10 grudnia 1925) uczeni z Polski i Czechosłowacji poparli koncepcje powstania na pograniczu polskoczechosłowackim parków natury i jednomyślnie określili zasady i ogólne ramy organizacyjne i terytorialne przyszłych obszarów chronionych, a także rozwiązania dotyczące turystyki. Przyjętym wzorcem stały się parki narodowe pogranicza amerykańsko-kanadyjskiego. Protokół konferencji opublikowany został w Krakowie w 1926 roku $^{10}$. W tym samym roku ogłoszony został w Pradze uzgodniony na spotkaniu w Krakowie projekt, do którego dołączona została schematyczna mapa transgranicznego parku narodowego w Tatrach. Projekt ten publikowany był później także w innych czechosłowackich wydawnictwach ${ }^{11}$. Mimo dużego zaangażowania obu stron, koncepcja utworzenia międzynarodowego rezerwatu przyrody $w$ Tatrach nie doczekała się realizacji $w$ okresie międzywojennym ${ }^{12}$. Główną barierą tego ambitnego przedsięwzięcia okazały się sprawy własnościowe, a także partykularne interesy różnych grup niezainteresowanych wprowadzaniem ograniczeń w dotychczasowym sposobie użytkowania tatrzańskiej przyrody ${ }^{13}$

Pomyślnie zakończyły się natomiast prace nad utworzeniem transgranicznego parku narodowego w Pieninach. Wstępny projekt rezerwatu o powierzchni 1650 ha opracowany został w latach 1921-1922. Rozpoczęte działania zostały zintensyfikowane po podpisaniu Protokołu krakowskiego, a także wspomnianych spotkaniach w Zakopanem i Krakowie. Ostatecznie 23 maja 1932 roku założony został w polskiej części pogranicza Pieniński Park Narodowy. Jednocześnie po drugiej stronie granicy powstał Stowacki Rezerwat Przyrodniczy. Dzięki temu na wspólnym pograniczu utworzony został pierwszy w Europie transgraniczny park narodowy. Tworzenie kolejnych obszarów chronionych na pograniczu polsko-czechosłowackim przerwał wybuch II wojny światowej ${ }^{14}$.

W Protokole krakowskim z 1924 roku przewidziano również zawarcie polsko-czechosłowackiej konwencji turystycznej mającej na celu ułatwienie swobodnego ruchu turystycznego na wspólnym pograniczu. Konwencja ostatecznie została podpisana w Pradze

\section{- ・ ・}

10 Na konferencji w Krakowie stronę polską reprezentowali wybitni naukowcy, m.in. Walery Goetel, Marian Sokołowski i Władysław Szafer, natomiast przedstawicielami strony czechosłowackiej byli: Karel Domin, Viktor Dvorský i Radim Kettner. Szerzej o idei powstania transgranicznych parków w regionie: W. Goetel, Parki Narodowe na pograniczu polsko-czechostowackim, „Wierchy” 1926, nr 4, s. 127-133; Odezwa uczonych polskich i czecho-stowackich w sprawie Narodowego Parku Tatrzańskiego, Ibidem, s. 133-135; Prirodný park v Tatrách, "Krásy Slovenska” 1925-26, nr 5, s. 19-21; W. Goetel, Dookoła utworzenia pogranicznych Parków Narodowych, "Wierchy” 1927, nr 5, s. 138-145; W. Siarzewski, Dzieje starań o ochronę Tatr i utworzenie międzynarodowego polsko-czechostowackiego Parku Przyrody, [w:] M. Gotkiewicz, Góry i góralszczyzna w dziejach i kulturze pogranicza polsko-stowackiego. Kultura i przyroda, Nowy Targ 2005, s. 155.

11 Zob. K. Domin, V. Mladejovský, Naše Tatry, Praha 1926, s. 526-547.

12 W czerwcu 1939 roku Ministerstwo Rolnictwa i Reform Rolnych wydało zarządzenie o utworzeniu Parku Narodowego w Tatrach. Nowy obszar chroniony objął jednak tylko polska czéść Tatr, tak więc nie miał on charakteru transgranicznego. Ponadto szybki wybuch wojny uniemożliwił dokończenie organizacji jego struktur.

13 Idei powołania parku narodowego sprzeciwiała się reprezentująca Niemców spiskich Zipser Deutsche Parte (ZDP), której członkowie gospodarowali po słowackiej stronie Tatr. Partia ta zorganizowała w 1925 roku masowy protest rolników i hodowców bydła w Kieżmarku. Przed wyborami 1929 roku delegacja ZPD przedłożyła rządowi czechosłowackiemu stanowisko partii, zgodnie z którym odmawiano współpracy z nowym rządem, w sytuacji gdyby w Tatrach miał powstać park narodowy. W 1931 roku także Czechosłowacka Partia Agrarna, dzięki sekretariatowi terenowemu w Liptowskim Mikulaszu, rozpoczęła w imieniu rolników tatrzańskich własną kampanię przeciwko powstaniu nowego parku. W. Siarzewski, Z dziejów ochrony Tatr, "Tatry" 2006, nr 4, s. 21.

14 M. Więckowski, Przyrodnicze uwarunkowania kształtowania się polsko-słowackich więzi transgranicznych, Warszawa 2004, s. 75. 
30 maja 1925 roku i weszła w życie rok później, 14 czerwca 1926 roku. Na jej podstawie wyznaczony został specjalny pas turystyczny obejmujący najciekawsze obszary turystyczne pogranicza. Pas ten składał się z trzech oddzielnych części, z których największa obejmowała tereny od Beskidu Śląskiego po Beskid Niski (ok. 10 tys. km²). Natomiast dwie pozostałe, znacznie mniejsze, zlokalizowane były w Karpatach Wschodnich, na terenach dzisiejszej Ukrainy. Zasięg terytorialny pasa turystycznego przedstawia poniższa mapa.

Mapa 1. Obszar polsko-czechosłowackiej konwencji turystycznej z 1926 roku

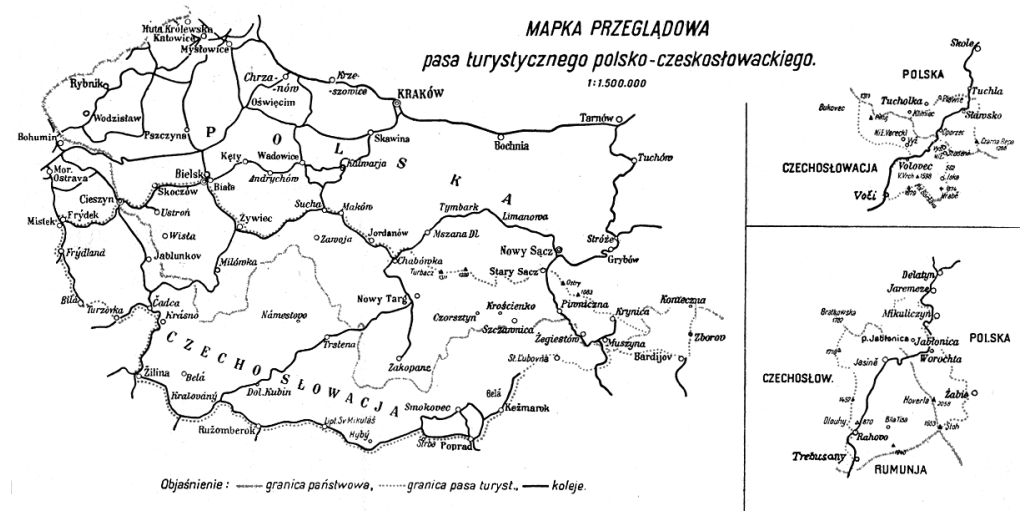

Źr ó dło: M. Orłowicz, Konwencja turystyczna polsko-czechosłowacka, „Wierchy” 1926, nr 4, s. 137.

W pasie turystycznym swobodę przekraczania granicy otrzymali członkowie określonych w umowie towarzystw turystycznych, a także wycieczki szkolne ${ }^{15}$. Według zapisów konwencji turyści mogli przekraczać granice nie tylko na drogach celnych, ale także turystycznych oznaczonych na mapach wojskowych. Po wejściu w życie umowy na obszarze konwencji wprowadzono specjalne zniżki kolejowe, powstały transgraniczne połączenia autobusowe i telefoniczne, towarzystwa turystyczne po obu stronach granicy zaczęły sobie udzielać wzajemnych zniżek w schroniskach. W celu ujednolicenia przepisów wykonawczych do konwencji oraz zapewnienia przestrzegania jej zapisów obie strony zobowiązały się do organizowania cyklicznych konferencji ${ }^{16}$. Zapisy umowy obowiązywały do wybuchu wojny w 1939 roku. Konwencja była pierwszą tego typu umową międzynarodową w Europie. Wprowadzała nowe rozwiązania dotyczące ułatwień w rozwoju turystyki transgranicznej w regionie, w którym do niedawna trwał konflikt graniczny ${ }^{17}$. Nowatorskie rozwiązania zastosowane w umowie stały się wzorcem dla innych państw europejskich ${ }^{18}$. Jednocześnie z konwencją podpisana została umowa o transgranicznej współpracy pomiędzy Polskim Towarzystwem Tatrzańskim a Czechosłowackim Klubem Turystów. Z ini-

15 Po polskiej stronie było to Polskie Towarzystwo Tatrzańskie i Polski Związek Narciarski, w Czechosłowacji natomiast Klub Czechosłowackich Turystów i Czechosłowacki Związek Narciarski. Istniała również możliwość rozciągnięcia praw wynikających z konwencji na inne organizacje.

16 M. Orłowicz, op. cit., s. 137; Konwencja turystyczna z Czechosłowacją i układ P.T.T. z towarzystwami turystycznemi czechosłowackiemi i jugostowiańskiemi, "Przegląd Turystyczny” 1925, nr 2, s. 3-5; Pas turystyczny polsko-czesko-stowacki, „Przegląd Turystyczny” 1932, nr 8, s. 15; M. Więckowski, Przyrodnicze uwarunkowania..., s. 190-192.

17 B. Morawska-Nowak, Tatry otwarte - Tatry zamknięte czyli granice a turystyka tatrzańska, „Pamiętnik Towarzystwa Tatrzańskiego" 1998, nr 7, s. 79-90.

18 W 1933 roku podobną konwencję turystyczną w regionie Alp podpisały Austria i Włochy. W dokumencie tym zastosowano bardzo dużo rozwiązań zawartych w umowie polsko-czechosłowackiej. Zob. Konwencja turystyczna włosko-austrjacka, „Przegląd Turystyczny” 1934, nr 10, s. 10. 
cjatywy tej pierwszej organizacji doszło również w 1925 roku do powstania ważnej międzynarodowej instytucji - Asocjacji Słowiańskich Towarzystw Turystycznych - która za główne zadanie turystyki w krajach Europy Środkowej uznała problem ochrony przyrody ${ }^{19}$.

Mimo pozytywnych doświadczeń w zakresie ochrony przyrody i turystyki sytuacja na wspólnym pograniczu nie została ustabilizowana na dłuższy czas. Rozstrzygnięcia z 1920 i 1924 roku przez cały okres międzywojenny postrzegane były przez stronę polską jako niesprawiedliwe. W konsekwencji stały się główną przyczyną wymuszenia przez rząd polski w dniach 30 listopada - 1 grudnia 1938 roku wymiany terytoriów z autonomiczną w tamtym okresie Słowacją. Należy jednak podkreślić, że korekta granicy na odcinku słowackim nie została narzucona militarnie, nie odbył się tam również żaden międzynarodowy arbitraż, jak to miało miejsce $w$ przypadku pozostałych granic Czechosłowacji. Nowa granica została ustalona na podstawie dwustronnych negocjacji polsko-słowackich. Ponadto, ze względu na prowadzoną wówczas przez Polskę politykę popierania nowego państwa słowackiego, nabytki na pograniczu słowackim ograniczyły się do 10 skrawków terenu, liczących łącznie 216,4 km². Strona polska świadomie zrezygnowała więc ze znacznie większych rewindykacji granicznych ${ }^{20}$.

\section{WSPÓtPRACA TRANSGRANICZNA W OKRESIE KOMUNISTYCZNYM}

Po zakończeniu II wojny światowej i wycofaniu się wojsk niemieckich sporne obszary ponownie objęła administracja polską. Nie uspokoiło to jednak sytuacji. Jeszcze przez kilka miesięcy $w$ regionie trwały regularne walki ze stroną słowacką. Sytuację ustabilizowało dopiero wkroczenie na Spisz i Orawę regularnych oddziałów Wojska Polskiego w lipcu 1945 roku. Dzięki temu, że Polska i Czechosłowacja znalazły się w obozie państw socjalistycznych polsko-słowacki konflikt graniczny został odgórnie "zamrożony". Z tego względu w pierwszych latach po wojnie prowadzona była delimitacja i demarkacja wspólnej granicy. Sporne kwestie graniczne wstępnie uregulował Układ o przyjaźni i wzajemnej współpracy z 10 marca 1947 roku. Ostateczne wytyczenie wspólnej granicy państwowej nastąpiło jednak dopiero na podstawie porozumienia podpisanego 13 czerwca 1958 roku. Stowacki odcinek granicy powrócił na linię ustaloną przez Ligę Narodów w latach 1920-1924²1.

Stosunkowo szybko przystąpiono do odtworzenia koncepcji ochrony przyrody na wspólnym pograniczu. Doświadczenia współpracy z okresu międzywojennego były na tyle duże, że stosunkowo szybko i skutecznie udało się odtworzyć transgraniczne obszary ochronne w regionie. Pierwszym krokiem w objęciu pełną ochroną Tatr było powołanie przez Ministra Leśnictwa w 1947 roku jednostki organizacyjnej lasów państwowych o nazwie Tatrzański Park Narodowy. Rok później decyzją Słowackiej Rady Narodowej powołany został

\section{......}

19 Konwencja turystyczna..., s. 6-7; W. Goetel, Asocjacja Stowiańskich Towarzystw Turystycznych, "Wierchy” 1926, nr 4, s. 141-145; Idem, Idea tączności wśród turystyki słowiańskiej, "Wierchy” 1927, nr 5, s. 148-151.

20 Polska przejęta od Stowacji w 1938 roku m.in. w Czadeckim ok. 40 km², na Orawie ok. 48 km² (wsie Sucha Góra i Głodówka), na Spiszu ok. 125 km² (Jaworzyna Spiska, Podspady, Golembark i Leśnica Pienińska), a także okolice Cigielki i źródeł Udawy (łącznie ok. 3 km²). Zob. J. Roszkowski, Kształtowanie..., s. 68; Polskie Towarzystwo Tatrzańskie i odzyskane ziemie górskie, „Wierchy” 1938, nr 16, s. 137-145; B. Zaborski, Zmiany granicy państwowej na pograniczu polsko-czesko-słowackim, „Biuletyn Związku Ziem Górskich” 1939, nr 1, s. 1-4.

21 M. Wenkler, Na flankach Podhala. Trudny powrót Spiszu i Orawy do Polski po Il wojny światowej, „Biuletyn Instytutu Pamięci Narodowej" 2010, nr 1-2, s. 56-62; T. Kisielewski, Z historii stosunków politycznych polsko-czechosłowackich oraz polsko-czeskich i polsko-słowackich, "Rocznik Nauk Politycznych" 2002, nr 4, s. 124; V. Kapičáková, Severná hranica Slovenska po roku 1945, [w:] R. Gładkiewicz, M. Homza (red.), Terra Scepusiensis. Stań badań nad dziejami Spiszu, Lewocza-Wrocław 2003, s. 940-944. 
Tatrzański Park Narodowy, a w 1954 roku rozporządzeniem Rady Ministrów w polskiej części pogranicza powstały Parki Narodowe: Tatrzański, Pieniński i Babiogórski. Od połowy lat 50. datuje się ścisłą współpracę tatrzańskich parków narodowych w zakresie ochrony przyrody i rozwiązywania ważnych problemów transgranicznych. Współpraca ta odbywała się zarówno na szczeblu administracji jak i rad naukowych obydwu parków²2. W 1967 roku ponownie objęto ochroną słowacką część Pienin, a w 1979 roku w słowackiej części Babiej Góry powstał park krajobrazowy Górna Orawa. W latach 70. transgraniczne obszary ochronne powstały także w Karpatach Wschodnich, w regionie Bieszczad²3.

Ponowne nawiązanie współpracy transgranicznej w zakresie ochrony przyrody stato się przyczynkiem do odtworzenia konwencji turystycznej z okresu międzywojennego. Jednak dopiero 6 września 1955 roku udało się Polsce i Czechosłowacji podpisać nową umowę o turystycznym ruchu przygranicznym, zwaną potocznie konwencją turystyczną. Początkowo wyznaczony pas turystyczny ograniczył się do Tatr Wysokich i Bielskich i był znacznie mniejszy od tego, który funkcjonował przed wojną. W latach 1961-1962, w wyniku dodatkowych umów, obszar konwencji powiększony został o część Tatr Zachodnich, utworzone zostały także obszary konwencyjne w Beskidzie Niskim i Karkonoszach ${ }^{24}$.

W ramach nowej konwencji wspólną granicę można było przekraczać na podstawie indywidualnych lub zbiorowych przepustek turystycznych. Organami odpowiedzialnymi za ich wydawanie stały się Komendy Miejskie lub Powiatowe Milicji Obywatelskiej właściwe dla stałego miejsca zamieszkania. Przepustki turystyczne mógł otrzymać każdy obywatel polski po ukończeniu 16. roku życia. Dokumenty te uprawniały do dwukrotnego w ciągu roku przekroczenia granicy państwowej, na dwóch z trzech obszarów konwencyjnych. Każdy turysta zobowiązany był posiadać odpowiedni przydział dewiz na wyjazdy turystyczne. Wycieczki zbiorowe na obszary turystyczne mogły organizować m.in. szkoły, organizacje turystyczne, polityczne, instytucje naukowe ${ }^{25}$. Wyznaczenie granic konwencji związane było przede wszystkim z rozwojem turystyki. Wprowadzenie przepisów łagodzących regulację transgranicznego ruchu miało jednak także duże znaczenie dla mieszkańców pogranicza. Ponownie nawiązane zostały przerwane po wojnie kontakty rodzinne na Spiszu i Orawie ${ }^{26}$.

Konwencja z okresu powojennego obejmowała obszar o powierzchni ok. 4700 km². Jego centralną część stanowiły Tatry i Podtatrze (zob. mapa 2). W skład tatrzańskiego obszaru konwencyjnego weszły największe atrakcje turystyczne regionu (m.in. jeziora Orawskie i Rożnowskie). Specjalnie dla strony polskiej rozszerzono strefę konwencji o leżącą w Niżnych Tatrach Dolinę Demianowską. W regionie Beskidu Niskiego powstał Dukielski obszar konwencyjny. Trzeci obszar wyznaczony został poza pograniczem polsko-słowackim, w regionie Karkonoszów. Generalnie granice konwencji stanowiły dna dolin okalających pasma górskie, wraz z transgranicznymi liniami kolejowymi i drogami, umożliwiającymi poruszanie się po sąsiednim państwie ${ }^{27}$. Umowa obowiązywała do wprowadzenia w Polsce stanu wojennego w 1981 roku. Po jego zniesieniu nie powrócono jednak do zapisów konwencji, a polsko-czechosłowackie relacje przez całe lata 80. charakteryzowała izolacja polityczna i społeczna, która w znacznym stopniu ograniczała kontakty transgraniczne ${ }^{28}$.

22 L. Niedzielski, L. Jakuczun, Wspótpraca Polski i Czechosłowacji w ochronie Tatr na nowej drodze, „Chrońmy Przyrodę Ojczystą" 1980, nr 3, s. 12-15.

23 M. Więckowski, Przyrodnicze uwarunkowania..., s. 76-77.

24 L. Herz, Rejon Tatr. Obszar konwencji turystycznej w CSRS, Warszawa 1962, s. 3.

25 A. Biedrzycki, Informator o tatrzańskim obszarze konwencji turystycznej w CSRS, Zakopane 1966, s. 7-9.

26 M. Więckowski, Przyrodnicze uwarunkowania..., s. 192.

27 S. Sosnowski, Obszar konwencji turystycznej w Czechostowacji, Warszawa 1976, s. 6-7

28 W. Malendowski, M. Ratajczak, Euroregiony. Polski krok do integracji, Wrocław 2000, s. 111. 
Mapa 2. Obszar tatrzański polsko-czechosłowackiej konwencji turystycznej z 1962 roku

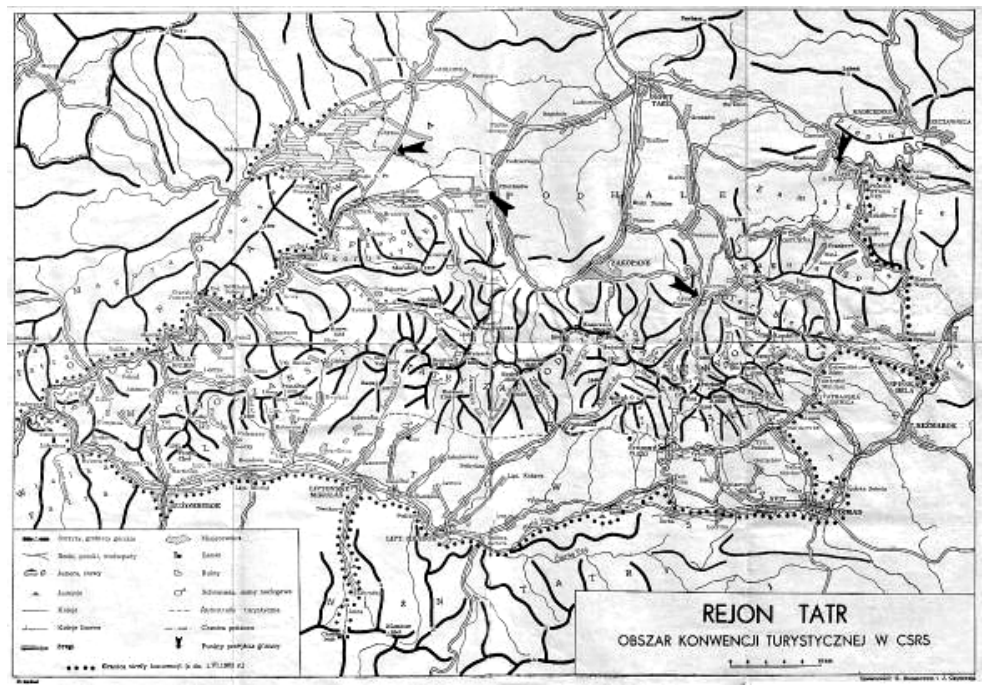

Źród o: L. Herz, op. cit., s. 97.

Reasumując, można stwierdzić, że stosunki polsko-czechosłowackie po 1918 roku charakteryzował pewien dualizm. Z jednej strony na wspólnej granicy istniały liczne konflikty, gtównie na tle etnicznym, o obszary przygraniczne, co utrudniało w dużym stopniu rozwijanie kooperacji transgranicznej. Z drugiej zaś rozwijała się, korzystna dla wspólnego sąsiedztwa, współpraca w zakresie ochrony przyrody, czego przykładem były powstałe po 1918 roku transgraniczne obszary chronione. Bardzo pozytywnie należy ocenić funkcjonowanie w regionie konwencji turystycznych, które wpłynęły głównie na rozwój turystyki transgranicznej. Przyczyniły się także do odnowienia, przerwanych po wojnie, kontaktów rodzinnych. Należy zaznaczyć, że konwencje na długo przed układem z Schengen, znosity utrudnienia w przekraczaniu granic i to na obszarach konfliktogennych. Wspólne parki narodowe i konwencje turystyczne były przykładami pierwszych w Polsce i Czechosłowacji transgranicznych jednostek terytorialnych. Doświadczenia ich funkcjonowania stały się wzorcem dla tworzących się na badanym obszarze euroregionów.

\section{INSTYTUCJONALIZACJA WSPÓtPRACY W RAMACH EUROREGIONU TATRY}

Obecnie w Europie najbardziej zinstytucjonalizowaną i najpopularniejszą formę transgranicznych powiązań stanowią euroregiony. W latach 90., w wyniku przemian społeczno-politycznych, procesy euroregionalizacji objęły także pogranicza państw Europy Środkowej i Wschodniej. Polska od początku transformacji, a Słowacja od 1999 roku aktywnie angażowały się w rozwijanie współpracy euroregionalnej na swoich granicach, czego efektem było powstanie 16 euroregionów w Polsce i 11 na Słowacji. Na wspólnym pograniczu działają obecnie 3 euroregiony. Jednym z nich jest Euroregion Tatry.

Idea zbliżenia i współpracy w rejonie Tatr po raz pierwszy pojawiła się na konferencji samorządowej w Zakopanem w 1991 roku. W kolejnych latach trwały konsultacje mię- 
dzy władzami samorządowymi i państwowymi dotyczącymi sformalizowania wzajemnych kontaktów transgranicznych. Sprawą powołania nowego euroregionu zainteresowały się również lokalne media. 31 października 1993 roku, kiedy Słowacja była już niepodległym państwem, podpisana została w Zakopanem deklaracja lokalnych samorządów dotycząca utworzenia Regionu Tatry ${ }^{29}$. Powstanie euroregionu wstrzymał wtedy sprzeciw rządu słowackiego. Pewne obawy wobec nowej inicjatywy pojawiły się również po stronie polskiej ${ }^{30}$. Mimo tych problemów 26 sierpnia 1994 roku zorganizowany został w Nowym Targu Kongres Założycielski, na którym podpisano umowę o założeniu Euroregionu Tatry ${ }^{31}$. 22 października 1999 roku, w piątą rocznicę działalności Euroregionu, na Nadzwyczajnym Kongresie zawarto nową wspólną umowę. W dokumencie tym pozytywnie oceniono dotychczasowe doświadczenia i dorobek Euroregionu. Przyjęta została także jego nowa nazwa - Transgraniczny Związek Euroregion Tatry. To wydarzenie zakończyło proces euroregionalizacji w regionie Tatr i Podtatrza ${ }^{32}$.

Euroregion Tatry posiada dobrze funkcjonujące struktury. Przez 17 lat swojej działalności wykształcił również doświadczone, profesjonalne kadry. Na jego strukturę wewnętrzną składają się: Kongres, Rada, Komisja Rewizyjna, Sekretarze i komisje robocze. Najwyższym organem stanowiącym jest Kongres, który ustala podstawowe kierunki działalności Euroregionu. Rada stanowi najwyższy organ wykonawczy Związku. Do jej kompetencji należy m.in. uchwalanie planów rzeczowo-finansowych, wykonywanie uchwał Kongresu. Funkcję pomocniczą wobec Rady pełnią Sekretarze, po jednym z każdej ze stron. Do ich zadań należy obsługa administracyjna struktur Euroregionu. W celu rozwiązywania konkretnych problemów transgranicznych powoływane są komisje robocze, które pełnią funkcje doradcze względem Rady ${ }^{33}$.

Dotychczasowa praktyka pokazuje, że Euroregion Tatry koncentruje swoją działalność na współpracy społeczno-kulturalnej. Z jego inicjatywy zorganizowano dużo ciekawych imprez kulturalnych, m.in. Dni Kultury Słowackiej, Dni Kultury Polskiej, Festyn Góralski Euroregion bez granic. Na szczególną uwagę zasługuje ostatnie duże przedsięwzięcie kulturalne - realizowany od 2006 roku projekt - Spotkanie siedmiu kultur pogranicza polskosłowackiego. W ramach projektu zorganizowana została już międzynarodowa konferencja naukowa, cykl wystaw lokalnych artystów, warsztaty muzyczne i koncert, wydane zostały także broszury i książki34. Ważnym osiągnięciem Euroregionu jest otwarty w 2004 roku Ośrodek Współpracy Polsko-Słowackiej w Nowym Targu. Pełni on rolę centrum kultury, informacji i promocji Euroregionu. Jest miejscem organizacji licznych spotkań, konferencji, koncertów i wystaw ${ }^{35}$. Ośrodek wielokrotnie odwiedzali najwyżsi przedstawiciele władz obu państw. Aby współpraca mieszkańców pogranicza była trwała i efektywna, musi być

\section{.......}

29 A. Nowak, A. Majorczyk, Euroregion Tatry 1994-1999, [w:] A. Nowak (red.), 5 lat Euroregionu Tatry 19941999, Nowy Targ-Kieżmark 1999, s. 7.

30 Władze stowackie argumentowały to obawami o dezintegrację terytorialną kraju. Ich zdaniem wyrażenie zgody na powstanie Euroregionu Tatry stanowitoby kolejną zachętę dla mieszkającej na Stowacji mniejszości węgierskiej w jej dążeniach do autonomii i ograniczania uprawnień władz centralnych na zdominowanych przez siebie południowych terytoriach. Rząd słowacki początkowo nie wyrażał zgody nawet na użycie słowa "euroregion" w nazwie tworzonego Związku. Pewne obawy dotyczące utworzenia Euroregionu pojawiły się także po stronie polskiej. Podczas sesji Rady Gminy Tatrzańskiej jeden z byłych radnych stwierdził publicznie, że powołanie Euroregionu może spowodować oderwanie od Polski Podhala. Zob. M. Grocholski, Tatry leżą w Europie, "Tygodnik Podhalański" 1994, nr 35, s. 1.

31 A. Nowak, A. Majorczyk, op. cit., s. 8.

32 Wspólna polsko-stowacka Strategia Rozwoju Euroregionu Tatry na lata 2008-2015, Kieżmark, s. 4-5.

33 A. Nowak, A. Majorczyk, op. cit., s. 10.

34 Idem, Euroregion Tatry - most polsko-stowackiej wspótpracy, [w:] J. Purchla (red.), Modele mecenatu państwa wobec integracji europejskiej. Doświadczenie Polski i Słowacji, Kraków 2008, s. 126-130.

35 Idem, Ośrodek Wspótpracy Polsko-Stowackiej w Nowym Targu, "Pogranicze Polsko-Stowackie” 2005, nr 2, s. 93-97. 
realizowana po obu stronach granicy. W tym celu konieczne stało się utworzenie podobnej instytucji także po słowackiej stronie granicy - od 2007 roku działa więc w Kieżmarku bliźniaczy ośrodek, Dom Spotkań Słowacko-Polskich Euroregionu Tatry ${ }^{36}$.

Euroregion Tatry realizuje również wiele inicjatyw gospodarczych i infrastrukturalnych. Najbardziej reprezentatywną imprezą w tym zakresie jest organizowane od 1999 roku Polsko-Stowackie Forum Gospodarcze. Biorą w nim udział przedsiębiorcy, reprezentanci izb przemysłowo-handlowych i turystycznych, a także politycy i dyplomaci z obu państw. Do chwili obecnej zorganizowanych zostało 9 tego rodzaju spotkań. Ostatnie z nich odbyło się 18 listopada 2010 roku w Spiskiej Nowej Wsi na Słowacji i stanowiło część projektu „Zielony Euroregion Tatry" ${ }^{37}$. Pieniądze pozyskane ze środków UE pozwoliły na realizację niektórych dużych projektów infrastrukturalnych. Do najważniejszych z nich zalicza się most Wyszehradzki, kładkę na Dunajcu łączącą Sromowce Niżne i Czerwony Klasztor, modernizację dróg Moszczenica-Konieczna. Ponadto wybudowano oczyszczalnie ścieków w Lipnicy Małej i Wielkiej, w Kieżmarku i Starej Lubowni, a także system kanalizacji sanitarnej w Żegiestowie-Zdroju. Z inicjatywy Euroregionu kontynuowano otwieranie nowych przejść granicznych na szlakach turystycznych Rysy, Muszyna-Legnava, Żegiestów-Sulin oraz Łapszanka-Osturnia. Zlikwidowany został również ruch tirów na przejściu granicznym Łysa Polana-Jaworzyna ${ }^{38}$.

Euroregion Tatry przygotowuje się do realizacji dużego strategicznego projektu Szlaku dookoła Tatr - liczącej ponad $200 \mathrm{~km}$ pętli obejmującej trasy rowerowe, piesze, narciarskie, konne i edukacyjne. Szlak ten ma w sposób kompleksowy i nowatorski pokazać walory regionów, przez które będzie przebiegał. Ma także spopularyzować wśród turystów aktywny sposób spędzania wolnego czasu. Według planów szlak ma stać się w przyszłości markowym produktem turystycznym. Tak duże przedsięwzięcie wymaga jednak znacznych nakładów finansowych, a jego finalizacja jest rozpatrywana w kilkunastoletniej perspektywie ${ }^{39}$.

\section{EUROPEJSKIE UGRUPOWANIE WSPÓLPRACY TERYTORIALNEJ „TATRY”}

Euroregion Tatry planuje pogłębienie poziomu integracji transgranicznej. Szansą na to jest nowy instrument prawny UE - Europejskie Ugrupowanie Współpracy Terytorialnej (EUWT). Posiada ono osobowość prawną. Umożliwia również stowarzyszania się samorządów z różnych państw bez konieczności podpisywania umów międzynarodowych. Nowe podmioty funkcjonują na podstawie prawa tego państwa, na którego terytorium znajduje się jego statutowa siedziba ${ }^{40}$. Pierwszym krokiem służącym przekształceniu Euroregionu Tatry w EUWT była uchwała XIII Kongresu Euroregionu Tatry z 16 marca 2007 roku zobowiązująca Radę do powołania specjalnej grupy roboczej, która miałaby się zająć monitoringiem procesu legislacyjnego EUWT w Polsce i na Słowacji oraz przygotować

36 R. Krafčiková, Dom Spotkań Stowacko-Polskich Euroregionu "Tatry” w Kieżmarku, „Pogranicze PolskoStowackie" 2008, nr 4, s. 7-10.

37 IX Stowacko-Polskie Forum Gospodarcze Euroregionu "Tatry", http://www.euroregion-tatry.eu/ix_slowacko polskie_forum_gospodarcze_euroregionu_tatry,63,n.html, [dostęp 25.01.2011].

38 A. Nowak, Dodatnie saldo, pytania o przyszłość, "Euroregiony-Polska” 2009, nr 80, s. 18-19; Sprawozdanie Rady Transgranicznego Związku Euroregion "Tatry" z działalności w 2008 roku, http://www.euroregiontatry.pl/akt/arch_2009/files/2009-04-21-SPRAWOZDANIE_RADY_XV_KONGRES_TZET,_17.04.2009.pdf [dostęp 20.02.2011]

39 A. Nowak, Euroregion Tatry-most..., s. 126-131.

40 S. Dołzbłasz, A. Raczyk, Wspótpraca transgraniczna w Polsce po akcesji do UE, Warszawa 2010, s. 200-205. 
odpowiednią dokumentację. Nowa Komisja ds. EUWT utworzona została 9 maja 2007 roku. Początkowo, ze względu na nieuregulowaną sytuację prawną w obu państwach, nie podejmowała ona żadnych konkretnych działań. Sytuacja zmieniła się w 2008 roku, kiedy Polska i Słowacja przyjęły ustawy regulujące tworzenie Ugrupowań ${ }^{41}$. Rada zobowiązała Komisję do wznowienia działalności i przygotowania na zbliżający się Kongres Euroregionu wniosków i dokumentów dotyczących możliwości transformacji Związku w EUWT42. Rezultatem kolejnych spotkań Komisji było opracowanie ramowych projektów Konwencji i Statutu EUWT, które zaprezentowano 17 kwietnia 2009 roku podczas XV Kongresu Euroregionu Tatry. W trakcie obrad przyjęta została również polsko-słowacka Deklaracja dotycząca utworzenia Europejskiego Ugrupowania Współpracy Terytorialnej, stanowiąca pierwszy formalny krok do ustanowienia nowego Ugrupowania ${ }^{43}$. W ten sposób zakończył się konceptualny etap tworzenia polsko-słowackiego EUWT.

Dużym problemem, z jakim borykał się Euroregion Tatry na pierwszym etapie przekształceń, były ograniczone środki finansowe. Prace nad powstaniem EUWT na Podtatrzu nabrały rozmachu wraz z przyjęciem na wspólnym pograniczu programu Polska-Słowacja 2007-2013. Władze Euroregionu uznały wtedy kwestię powołania EUWT za jeden ze swoich głównych priorytetów. W marcu 2010 roku Kongres zarekomendował do realizacji projekt strategiczny „Od Euroregionu Tatry do Europejskiego Ugrupowania Współpracy Terytorialnej". Po dokonaniu oceny wniosku przez Komitet Monitorujący został on w grudniu 2010 roku zatwierdzony do dofinansowania ${ }^{44}$. Projekt ten ma pomóc w sfinansowaniu stosunkowo kosztownej budowy struktur nowego EUWT i w ten sposób przyczynić się do finalizacji zapoczątkowanego w 2007 roku procesu przekształceń instytucjonalno-prawnych ${ }^{45}$. Kieruje projektem strona polska Euroregionu Tatry, pozostając w partnerstwie ze Związkiem Region Tatry w Kieżmarku oraz miastami Nowy Targ i Kieżmark. Podstawowym celem przedsięwzięcia jest podniesienie polsko-słowackiej współpracy transgranicznej na wyższy poziom organizacyjno-prawny. Bezpośrednimi beneficjentami inicjatywy mają być jednostki samorządu terytorialnego tworzące Euroregion Tatry. Dzięki nowym możliwościom, jakie daje EUWT, oddziaływaniem projektu pośrednio objęta zostanie również społeczność lokalna pogranicza polsko-słowackiego ${ }^{46}$.

Obecnie Euroregion Tatry jest w trakcie opracowywania podstawowych dokumentów nowego Ugrupowania (pierwszy etap projektu). Na ostatnim Kongresie Związku Euroregion Tatry, który odbył się 2 marca 2011 roku w Łapszach Niżnych, przyjęty został projekt Konwencji o powołaniu Europejskiego Ugrupowania Wspótpracy Terytorialnej "Tatry". Podczas spotkania członkowie Komisji ds. EUWT zobowiązani zostali do dalszych prac nad Konwencją i Statutem oraz prezentacji ich ostatecznych wersji do zatwierdzenia przez nadzwyczajne Kongresy Euroregionu Tatry do końca III kwartału 2011 roku. Rada i Dyrek-

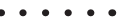

41 Sprawozdanie Rady Transgranicznego Związku Euroregion Tatry z działalności w 2008 roku, Materiały Biura Euroregionu Tatry w Nowym Targu, s. 5-6.

42 Uchwała Nr 3 XIV Kongresu Transgranicznego Związku Euroregionu "Tatry" z dnia 28.03.2008 r. w sprawie: Europejskich Ugrupowań Wspótpracy Terytorialnej (EUWT), Materiały Biura Euroregionu Tatry w Nowym Targu.

43 Uchwała Nr 3 XV Kongresu Transgranicznego Związku Euroregion "Tatry” z dnia 17.04.2009 r. w sprawie: Deklaracji dotyczącej utworzenia Europejskiego Ugrupowania Wspótpracy Terytorialnej, Materiały Biura Euroregionu Tatry w Nowym Targu.

44 Posiedzenie Komitetu Monitorującego 14-15 grudnia 2010 - lista projektów zatwierdzonych do dofinansowania, http://pl.plsk.eu/news/?lang_id=3\&id_news=644, s. 6, [dostęp 10.03.2011].

45 Uchwała Nr 2 XVI Kongresu Transgranicznego Związku Euroregion "Tatry" z dnia 24.03.2010 r. w sprawie: projektów strategicznych Transgranicznego Związku Euroregion "Tatry", Materiały Biura Euroregionu Tatry w Nowym Targu.

46 Od Euroregionu "Tatry" do Europejskiego Ugrupowania Wspótpracy Terytorialnej, Materiały Euroregionu Tatry w Nowym Targu, s. 2-4. 
tor biura Euroregionu w Nowym Targu upoważnieni zostali przez Kongres do zwrócenia się z prośbą do Zarządu i Sejmiku Województwa Małopolskiego o wsparcie działań służących powołaniu nowego EUWT, a także o wsparcie finansowe ${ }^{47}$.

Zgodnie z projektem Konwencji oficjalna nazwa nowego Ugrupowania będzie brzmieć: Europejskie Ugrupowanie Współpracy Terytorialnej „Tatry”. EUWT tworzyć będą strony krajowe Euroregionu Tatry, a także miasta Nowy Targ i Kieżmark. Organy wymagane przez Konwencję to: Walne Zgromadzenie, Zarząd, Komisja Rewizyjna oraz Dyrektoriat ds. Funduszy Europejskich. Natomiast gtównym celem Ugrupowania będzie dalszy rozwój polsko-słowackiej współpracy transgranicznej w wymiarze gospodarczym, społecznym i środowiskowym, zgodnie z zasadami partnerstwa i równoprawności stron. Realizacja powyższych zadań ma być możliwa dzięki programom i projektom współpracy transgranicznej wspótfinansowanym przez UE ${ }^{48}$.

Uchwałę o przystąpieniu do Ugrupowania podejmą Kongresy narodowe Euroregionu Tatry. Po stronie polskiej decyzja taka wymaga zwykłej większości głosów co najmniej połowy delegatów. Natomiast w części słowackiej Euroregionu zakłada się możliwość dwóch trybów podejmowania takiej uchwały: zwykłą większością głosów obecnych delegatów lub bezwzględną większością głosów ustawowego składu. Zgodę na przystąpienie do EUWT po stronie polskiej wyraża Minister Spraw Zagranicznych w porozumieniu z ministrami właściwymi do spraw wewnętrznych, finansów i rozwoju regionalnego. Analogiczną decyzję po stronie słowackiej wydaje Ministerstwo Budownictwa i Rozwoju Regionalnego. Po otrzymaniu pozytywnej decyzji resortów, członkowie EUWT zobligowani będą do zwołania pierwszego Walnego Zgromadzenia, na którym jednogłośnie powinny być przyjęte zapisy Konwencji i Statutu. Kolejnym krokiem jest procedura wpisania nowego podmiotu do Rejestru EUWT. W terminie 10 dni od tego faktu zgłaszany będzie wniosek do Urzędu Oficjalnych Publikacji WE na temat publikacji w Dzienniku Urzędowym UE informacji o jego powstaniu. Zgodnie z projektem Konwencji rozwiązanie Ugrupowania Tatry będzie mogło nastąpić na podstawie uchwały Walnego Zgromadzenia, wystąpienia jednego z członków, wygaśnięcia czasu funkcjonowania Ugrupowania, decyzji o likwidacji podjętej przez organ rejestrowy lub sąd oraz ogłoszenia upadłości. Kontrolę finansową w EUWT Tatry przeprowadzać będą odpowiednie organy tego państwa, w którym znajdować się będzie siedziba statutowa Ugrupowania. Wszystkie kontrole organizowane będą zgodnie z międzynarodowymi standardami audytu. EUWT Tatry powołane zostanie na czas nieokreślony. Nie będzie się ono mogło łączyć z innymi Ugrupowaniami, nie dopuszcza się również jego podziału. Sama Konwencja wejdzie w życie z chwilą rejestracji Ugrupowania ${ }^{49}$.

Przyjęty na ostatnim Kongresie projekt Konwencji pozostawia część spraw do uregulowania w trakcie dalszej dyskusji. Najwięcej kontrowersji budzi przede wszystkim wybór siedziby nowego EUWT, i co za tym idzie, systemu prawnego według, którego będzie ono funkcjonować. Jedna z propozycji mówi o zlokalizowaniu siedziby EUWT w Kieżmarku, ponieważ prawo gospodarcze i podatkowe na Słowacji jest bardziej przyjazne dla tego rodzaju działalności niż w Polsce. Nie bez znaczenia jest również fakt, że oficjalną walutą tego kraju jest euro. Natomiast w Nowym Targu mieścitby się Dyrektoriat ds. Funduszy Europejskich, który zarządzałby programem i funduszami UE. Lokalizacja ta świadczyłaby

\section{-....}

47 Uchwała Nr 2 XVII Kongresu Związku Euroregion "Tatry" z dnia 02.03.2011 r. w sprawie: Europejskiego Ugrupowania Wspótpracy Terytorialnej, Materiały Biura Euroregionu Tatry w Nowym Targu.

48 Konwencja o powołaniu Europejskiego Ugrupowania Wspótpracy Terytorialnej "Tatry" (projekt), Materiały Biura Euroregionu Tatry w Nowym Targu, s. 1-4.

49 Ibidem, s. 4-6. 
o uznaniu dotychczasowych osiągnięć strony polskiej w zarządzaniu mikroprojektami ${ }^{50}$. Wydaje się, że podstawową przeszkodą na tym etapie tworzenia EUWT Tatry jest wciąż obecna nieufność po obu stronach granicy i pewna niechęć przed przekazywaniem zadań organom wspólnym, szczególnie w zakresie finansowania i zarządzania projektami. Otwartą kwestią pozostaje również stosunek do nowej inicjatywy władz centralnych obu państw.

\section{ZAKOŃCZENIE}

Po 1918 roku w regionie Tatr i Podtatrza powstało szereg ciekawych inicjatyw transgranicznych. Pomyślnie rozwijała się współpraca w zakresie ochrony przyrody, czego przykładem były powstałe wspólne obszary chronione. Pozytywnie należy również ocenić funkcjonowanie w regionie konwencji turystycznych, które wpłynęły na rozwój turystyki transgranicznej i ułatwiły kontakty między mieszkańcami pogranicza. Należy zaznaczyć, że konwencje na długo przed układem z Schengen znosiły utrudnienia w przekraczaniu granic i to na obszarach konfliktogennych. Wspólne parki narodowe i konwencje turystyczne były przykładami pierwszych w Polsce i Czechosłowacji transgranicznych jednostek terytorialnych. Doświadczenia ich funkcjonowania stały się wzorcem dla założonego w latach 90. Euroregionu Tatry. Jest to obecnie najbardziej zinstytucjonalizowana organizacja transgraniczna na badanym obszarze. Od 17 lat aktywnie i profesjonalnie realizuje ona polskosłowacką współprace transgraniczną. W najbliższym czasie planowane jest przekształcenie Związku w Europejskie Ugrupowanie Współpracy Terytorialnej.

POLISH-SLOVAK TRANS-FRONTIER COOPERATION IN THE TATRA MOUNTAIN REGION AFTER 1918

\section{Summary}

The aim of this article is to analyse the most significant forms of trans-frontier cooperation on the Polish-Slovak common borderland since 1918. The analysis is presented chronologically, divided into stages. Polish-Czechoslovak trans-frontier cooperation is discussed in the first part of the article, including such issues as the original protected common areas, for example the Pieniny Mountains, and the convention on tourism signed in 1925. Between 1945 and 1993 the majority of the national parks in the Tatra and Sub-Tatra regions were established, and in 1956 a second Polish-Czechoslovak convention on tourism was signed. The last part of the article discusses the Trans-frontier Union of the Tatra Euroregion as a contemporarily institutionalised form of Polish-Slovak cooperation. The newest legal institution of the European Union, the European Grouping of Territorial Cooperation, is also presented. The Euroregion's final goal is to be converted into this grouping in the near future.

Keywords: Tatra Euroregion, borderland, trans-frontier cooperation

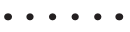

50 A. Nowak, Tak blisko, a jednak inaczej, „Europrojekty.pl” 2011, nr 3, s. 19. 